\title{
Motivation of Taking Distance-Learning and Online Programmes: A Case Study in a TAFE Institution in Australia
}

\author{
Luis M. Dos Santos \\ Woosong Language Institute, Woosong University, \\ 196-5 Jayang Dong, Daejeon, 34514, \\ South Korea
}

DOI: https://doi.org/10.36941/ajis-2021-0149

\begin{abstract}
The distance-learning and online courses and programmes are popular during the COVID-19 Pandemic due to the recommendation of social distancing and closure of borders in Australia. The purpose of this study is to explore and understand the motivation and decision-making processes of international students who continue their academic courses and programmes using online distance-learning platforms under the COVID-19 Pandemic. With the case study design, the researcher recruited 20 international students who are currently completing their academic courses and programmes through distance-learning from a Technical and Future Education (TAFE) institution in Australia. Based on the Social Cognitive Career and Motivation Theory, the researcher categorised that the educational achievements and career goals, the achievements of education and career goals, and interests in career development drove the factors of their motivation and career-decision-making process. The results of this study will provide a blueprint for school leaders, department heads, government agencies, policymakers, and researchers to reform and upgrade the current curriculum for technologically-assisted teaching and learning strategies and international students' experiences.
\end{abstract}

Keywords: distance-learning, online courses, COVID-19, Australia

\section{Introduction}

\subsection{Background}

The COVID-19 Pandemic has changed the teaching and learning strategies of students, teachers, and schools. Before the COVID-19 Pandemic, many academic courses and programmes were offered through face-to-face teaching and learning, requiring on-campus attendance and interaction between classmates and teachers in a classroom environment. Although online distance-learning and blended courses were available, many programmes were completed via the traditional on-campus mode.

In the early 2020s, due to the rapid onset of the COVID-19 Pandemic, the Australian government decided to restrict the entry of non-Australian citizens and temporary residents. Consequently, individuals without Australian leave to remain cannot enter Australia without special permission. Although many academic programmes restarted face-to-face or blended learning during the September 2020 term, international students who had left the country before the closure 
continued their learning via distance-learning and online platforms.

Some scholars (Simpson, 2018; Yamagata-Lynch et al., 2015) argue that if schools and instructors are willing to make additional preparations in coursework design and the curriculum, students can receive similar learning outcomes and performance via distance-learning. However, a previous study (Alqurashi, 2017) indicated that instructors, students, and parents all need to be well prepared in order to achieve their expectations. For example, even if a school and curriculum designer establish a tailor-made curriculum and plan for a particular course or module, the outcomes cannot be guaranteed if one party (i.e., the instructor, student, or parent) misses any parts. Although instructors may be equipped with excellent teaching and learning plans, students could miss part of the lessons due to the distance-learning environment of their own bedrooms.

Although there are many disadvantages of distance-based teaching and learning strategies, there are also positive effects. Distance-learning education provides safe, flexible, convenient, and achievable teaching and learning platforms for students who cannot attend traditional face-to-face lessons. Many studies (Bates \& Khasawneh, 2007; Dos Santos, 2020f) have indicated that the development of tools for technologically-assisted teaching and learning has connected students from remote locations to cities via the internet. Although there are some vocational and practical skills that cannot be delivered using purely visual materials, students can come on-site for final exams or essential demonstrations.

Distance-learning education can reduce costs for all parties (i.e., students, parents, schools, and instructors) including time costs, financial considerations, and other personal factors. A previous study (Mozelius \& Hettiarachchi, 2017) indicated that schools and universities require fewer classroom arrangements, as well as utilities, instructors, supplies, and teaching and learning tools when using distance-learning in comparison to the traditional classroom environment. It is not necessary for both instructors and students to physically visit the classroom for lessons, or to spend additional resources on transportation between home and the classroom. Some scholars have suggested that distance-learning instruction and classroom environments are likely to become a trend, particularly following the COVID-19 Pandemic.

\subsection{Purpose of the Study}

The purpose of this study is to explore and understand the motivation and decision-making processes of international students who continue their academic courses and programmes using online distance-learning platforms under the COVID-19 Pandemic. Unlike domestic students who may have local connections with part-time jobs and family responsibilities, international students tend to study on-campus in order to gain language skills and cultural experience from teachers and classmates, as well as the experience of living in Australia. However, due to the COVID-19 Pandemic, many international students decided to pause their academic voyage until a later date. Many countries and regions, such as the United Kingdom and the United States continued to issue student visas for international university students, and therefore, many students moved their education destination to other countries. As a result of these changes and based on the Social Cognitive Career and Motivation Theory (Dos Santos, 2021a; Lent et al., 1994; Lent \& Brown, 1996), the current study was guided by two research questions:

1) Why do international students decide to continue their academic programmes through the distance-learning option during the COVID-19 Pandemic at a TAFE institution in Australia?

2) How do international students describe their motivation and decision-making processes in studying distance-learning programmes during the COVID-19 Pandemic at a TAFE institution in Australia?

\subsection{Significance of the Study}

The results and outcomes of this study will be useful in two ways. First, most of the courses and 
programmes from the TAFE institutions were traditionally delivered face-to-face (i.e., on-campus with physical attendance). Although a small portion of the courses have blended or distance-learning options, most students prefer face-to-face lessons with their classmates and teachers. However, the COVID-19 Pandemic changed the expectations of all parties. The results of the study may provide recommendations and ideas to programme and institutional leaders for further reforms and development. Second, government leaders and policymakers will benefit from the results as some of the curriculum plans and methodology need to be approved by them. The comments and opinions of the learners will be useful in implementing better arrangements and development. Therefore, with the ideas from the learners, all parties may benefit from the results of this study.

\subsection{Theoretical Framework: Social Cognitive Career and Motivation Theory}

The Social Cognitive Career and Theory Theory (Dos Santos, 2021a; Lent et al., 1994; Lent \& Brown, 1996) was the theoretical framework for the investigation. The Social Cognitive Career and Theory Theory was developed based on the development of Social Cognitive Career Theory (Lent et al., 1994). However, due to the rapid development of the global communities, the researcher believed that the aged theory could not cover the directions and motivations of individuals and groups. As a result, the current study employed the Social Cognitive Career and Theory Theory as the channel for investigation.

The Social Cognitive Career and Theory Theory (Dos Santos, 2021a) advocated that individuals' motivations, career decisions, decision-making processes, and intentions can be influenced by two major factors, including the psychological and internal factors with self-efficacy, and social external factors. Under the umbrella of psychological and internal factors with self-efficacy, individuals' motivations, career decisions, decision-making processes, and intentions can be influenced by 1) academic interests, 2) personal considerations, and 3) achievements of education and career goal. In addition, social and external factors may influence individuals' motivations, career decisions, decision-making processes, and intentions with 1) interests in career development, 2) financial consideration, and 3) Surrounding environments and individuals. For details, please refer to Figure 1.

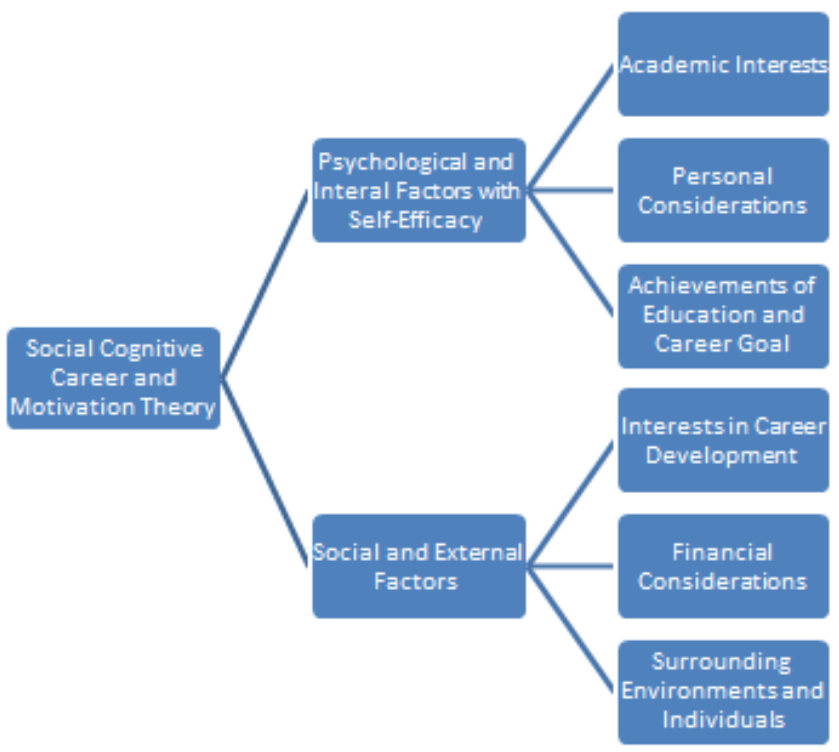

Figure 1. Social Cognitive Career and Motivation Theory 


\subsection{Definition of Terms}

COVID-19 Pandemic refers to a global crisis in public health. Due to the COVID-19 Pandemic, many colleges and universities need to offer distance-learning and online learning options to students who cannot attend the physical lessons on-campus.

Social distancing recommendation refers to a government policy related to public health requirements. Individuals should stay at least 1.5 meters away from each other to protect their health.

TAFE institution refers to the technical and further education institution. In some countries, TAFE institutions are known as institutions of technology or polytechnics (New Zealand), community colleges (United States), higher education institutions (United Kingdom), and schools of continuing education. In Australia, TAFE institutions offer different levels of vocational courses across the country, particularly in post-secondary education. TAFE institutions may award qualifications based on the Australian Qualification Framework (AQF) from Certificate I, Certificate II, Certificate III, Certificate IV, Diploma, Advanced Diploma, Graduate Certificate to Graduate Diploma.

\section{Materials and Methods}

\subsection{The Qualitative Research Design: Case Study}

The case study (Yin, 2012) was employed in this study. This approach was employed because the researcher wants to understand and explore why international students decide to continue their academic programmes through the distance-learning option during the COVID-19 Pandemic at a TAFE institution in Australia. The case study design offers some advantages for this study. First, unlike other qualitative designs with a wider perspective, the case study design tends to capture the ideas and directions with a target group of participants and site. The comments and opinions from these groups of participants and site(s) are rich and meaningful for further reflection at similar backgrounds and setting.

\subsection{Recruitment and Participants}

The purposive sampling strategy (Creswell, 2014; Merriam, 2009) was employed to recruit 20 participants. First of all, the researcher contacted TAFE administrator for the potential coordination of this study. The administrator referred my desire, rationale of the study, research protocol, invitation letter, and related materials to the upper leadership for further discussion. After several rounds of discussions, the upper management approved the study. Second, the researcher asked the administrator to send the related materials to the potential participants (i.e. students). Third, 20 participants decided to join this study. As this study focused on the motivation and decision-making processes of international students, the participants should meet all of the following,

- Identify as an international student;

- Currently enrolled as a student at a TAFE in Australia;

- Have completed at least one academic term in Australia prior to the closure;

- Studying their academic programme(s) through the distance-learning option during the COVID-19 Pandemic;

- Currently living outsides of Australia;

- At least 18 years old;

- Non-Vulnerable person.

\subsection{Data Collection}

Two tools were employed for the data collection, including interview sessions and focus group 
activities. First, the researcher based on the agreement (i.e. consent form), all participants should complete two interview sessions. The interview sessions were one-on-one and semi-structured interview sessions. Unlike the traditional face-to-face interview sessions, as the participants were all located in different parts of the world, it was impossible to conduct the interview sessions in person. Due to the development of the distance-based interview tools, the researcher invited the participants for the distance-based interview sessions twice. For the first interview session, the researcher focused on the interview protocol for research questions \#1, while the second interview session was about research question \#2. Each interview session lasted from 77 to 109 minutes.

Second, after the researcher completed all of the interview sessions (i.e. 40 interview sessions), the researcher invited all participants for the focus group activities. As recommended by a qualitative researcher (Morgan, 1998), the focus group activities should be intensive and concentrated. Therefore, the researcher invited five participants for each focus group activity. In other words, four focus group activities were hosted. Again, as all participants were currently living in different parts of the world, only distance-based focus group activities could be conducted. Each focus group activity lasted from 112 to 123 minutes.

Third, member checking interview sessions were hosted individually for confirmation. Once the researcher categorised the materials, the researcher sent the related materials back to each participant for confirmation. Finally, the researcher invited the participants for an individual member checking interview. Each member checking interview lasted from 32 to 46 minutes. All participants agreed and confirmed their materials.

Please note that a digital recorder recorded all the interview sessions and focus group activities. The participants have notified of this arrangement with their consent form. However, the researcher also reminded them of the recording arrangement before the session. All agreed with the arrangement.

\subsection{Data Analysis}

The grounded theory approach (Strauss \& Corbin, 1990) is useful for this study. First of all, the researcher transcribed the voiced messages to written transcripts for the data analysis. Then, the researcher re-read the materials multiple times for the potential connections. Second, the researcher employed the open-coding technique for the first-level themes and subthemes. Although many lived stories and comments were different, many similarities and points could be merged. As a result, 11 themes and 12 subthemes were concluded. However, based on the recommendations of qualitative researchers (Creswell, 2012; Merriam, 2009; Tang \& Dos Santos, 2017), additional development is needed. Therefore, the researcher employed the axial-coding technique for the second-level themes and subthemes. As a result, three themes and two subthemes were merged.

\subsection{Human Subject Protection}

Privacy for all parties is the most important element in this study. All the signed agreements, personal contacts, email addresses, voiced messages, written transcripts, computer, and related materials were locked in a password-protected cabinet. Only the researcher could read the materials. After the researcher completed the study, all related materials were deleted and destroyed for personal privacy. The current study was supported by the Woosong University Academic Research Funding 2021.

\section{Results and Discussions}

Although all the students are from different backgrounds, courses, and programmes, many similar answers and ideas were identified. Based on the theoretical framework, the researcher captured three themes and two subthemes from the data collection procedure (two interview sessions and one focus group activity). Table 1 refers to the themes and subthemes. 
Table 1. Themes and subthemes.

\begin{tabular}{lll}
\hline & \multicolumn{1}{c}{ Themes and subthemes } \\
\hline 3.1. & 3.1.1. & $\begin{array}{l}\text { The desire to complete and finish education and programmes } \\
\text { COVID-19 Pandemic does not limit learning motivation } \\
\text { 3.2. }\end{array}$ \\
3.3. & 3.2.1. & $\begin{array}{l}\text { Distance-learning should be developed as a long-term option } \\
\text { The interaction between teachers and classmates remain the same }\end{array}$ \\
\hline
\end{tabular}

\subsection{The Desire to Complete and Finish Education and Programmes}

According to a recent study (Thatcher et al., 2020), many students' academic plans were interrupted due to the COVID-19 Pandemic, social distancing recommendations, and the closure of the Australian border in early $\mathbf{2 0 2 0}$ as most international students could not return to Australia for their academic programmes due to government policies. Before the global crisis of the COVID-19 Pandemic, most courses and programmes were offered face-to-face with an expectation of physical interaction between classmates and teachers. A recent study (Ewing \& Cooper, 2021) reflects that as a response to the global crisis, many schools and teachers switched their teaching and learning approach to distance-learning. The following participants shared their views on the sudden switch from face-to-face to a distance-learning approach,

...I was enrolled into the face-to-face courses...because I want to talk to my peers and teachers...but I returned to my home for the new year with my families...but I could not go back to Australia...because the government closed the border...but I am okay with the online courses...I am okay with it because I can talk to my teachers... and I can read the materials and homework too...the learning outcomes are the same...(Participant \#12, Interview)

...I was surprised because of the sudden closure of the Australian border...I planned to go back to Australia...two days after the closure...I called the airline company...but all tickets were fully booked...I called my school...and my school told me that I could take a break or continue with the online courses...because I want to finish the programme as soon as possible...I am two terms away from graduation...then I can apply for university...I will complete it...no problem...(Participant \#1o, Interview)

Many students expressed their disappointment at the closure of the Australian border and the termination of entry for non-Australian citizens and temporary residents. Although all international students were likely to hold a re-entry permit, they were not able to return before the border closure. However, their school offered a distance-learning option, an approach that was uncommon for their courses and programmes. All decided to continue with their courses and programmes with the distance-learning options. The following comments were made about their decision-making processes, motivations, and reasons,

...it was not an easy step...many of my classmates stopped their study...because they wanted to go to Australia for the on-campus study...they wanted to live in Australia and learnt the knowledge from their teachers...many wanted to learn English in Australia...many wanted to do the internship in some companies...but the online courses...we could not live in Australia...it is hard...because people paid for the opportunities... but, I have a strong mind...I want to finish the courses...and I can go to a university afterwards...(Participant \#2, Interview)

...I talked to my parents...I talked to my classmates...and I talked to my teachers in my school...I decided to continue...because going to university after the TAFE is my goal...the TAFE education is just a stepping stone...it is the first year of my university degree...so I need to continue...no problems...once I finished the programme in the TAFE...I will consider it again...for university degree...but let's see...(Participant \#5, Focus Group) 
In short, according to some previous studies (Brown et al., 2015; Dos Santos, 2020b, 2021b; Pozdnyakova \& Pozdnyakov, 2017; Simpson, 2018) have identified distance-learning as an alternative way to complete a qualification. Some recent studies indicated that flexibility, location-free access, and self-paced learning are key in distance-learning options and programmes. Although most students started their programmes with a face-to-face approach, many young adults are used to technologically-assisted teaching and learning options (Almog et al., 2018; Booy et al., 2012; Dos Santos, 2020a, 2021b, 2020c). Finding little difficulty in technology and online learning, many continued with their programmes.

\subsubsection{COVID-19 Pandemic does not Limit Learning Motivation}

Many participants felt that the COVID-19 Pandemic and the closure of the Australian border had significantly limited the motivation and intentions of their classmates. It was not uncommon for students to pause their study as they had expected face-to-face lessons and internships in Australia. As the closure of the Australian border did not meet their expectations and hopes, it would have been expected that many students might pause their studies. However, in this case study, all participants had continued with their studies and completed (or would complete) their qualification using online distance-learning. The researcher captured some comments concerning the relationship between the COVID-19 Pandemic and the desire for education,

...COVID-19 Pandemic is hard...but this social issue will not stop my plan for university...I need to complete my certificate and diploma...I have to go to university...the COVID-19 Pandemic.... will not make any differences...online courses...will not limit my knowledge...my goal is going to university afterwards...if I can continue my courses online...and I can receive the same diploma....and apply to university...why not? I need to finish and achieve my goals...the TAFE school is my first step...the first step...should be finished...(Participant \#8, Focus Group)

...I want to make sure all of us are safe...I can stay at home...I can spend good time with my parents and good friends in my homeland...I can continue with my Australian education...it is so good...the COVID19 Pandemic...cannot control me...I will complete my diploma and go to university...after this term...no one can stop me...(Participant \#1, Focus Group)

In conclusion, based on the Social Cognitive Career and Motivation Theory (Dos Santos, 2021a; Lent et al., 1994; Lent \& Brown, 1996), the participants confirmed that their educational achievements and career goals significantly influenced their motivation and decision-making processes. As highlighted in previous studies (Heidrich et al., 2018; Smith, 2008), the participants expressed their intention to go to university after the completion of their TAFE qualification. Although the COVID-19 Pandemic restricted face-to-face interaction, the flexibility to complete qualifications at their convenience increased their motivation and intentions.

\subsection{Technology should be Employed in Education}

Technologically-assisted teaching and learning are already used in many classroom environments across the globe. Previous studies have indicated that teachers have tended to employ technologically-assisted tools in face-to-face classrooms (Blazar et al., 2018; Espino et al., 2020), such as listening, video watching, and Microsoft PowerPoint presentations. However, many teachers are not ready for full online teaching using distance-based learning tools and platforms (Moorhouse, 2020; Pike, 2015). Some participants expressed their concern in the technologically-assisted teaching of their teachers, particularly as international students, 
...I returned to my homeland...I have different time zone with my teachers and classmates in Australia...some of my courses...we had to have the live lessons...yes, I am a full-time student...but I still need to sleep...I cannot attend my classes at $4 A M$ in the morning...I expressed my concerns with my schools...but they couldn't solve it immediately...(Participant \#3, Focus Group)

...some teachers were not ready for the online courses...I understood...for old teachers...they don't use PowerPoint but only textbooks...but they could not scan the reading on-time...and ask us to answer the questions from the reading materials...also, I hope to have PowerPoint for the lessons...I looked at the face of my teachers...it is not interesting...(Participant \#14, Focus Group)

In short, some participants expressed their concerns in the disadvantages of the current technologically-assisted teaching and learning approaches in the classroom environment. As indicated in previous studies (Austin, 2010; Floyd, 2003; Kaur, 2013), administrative departments, teachers, information technology support, and student services departments are not all ready for full online teaching and learning, particularly with when there is limited preparation time. The sudden changes may reduce the motivation and interest of students in their learning experiences and performance.

\subsubsection{Distance-Learning Should be Developed as a Long-term Option}

The COVID-19 Pandemic offers the opportunity to reform and invest in distance-learning courses and programmes for many Australian TAFE institutions and universities. Many Australian universities have already invested in distance-learning courses and programmes for both domestic and international students, such as the Open Universities Australia system (OUA). Open Universities Australia is a public university consortium offering various courses and programmes from many Australian universities. Students can enrol on most of the courses and programmes online, except for some internships and placements. Following the development of different types of distance-learning options, many participants expressed their desire for distance-learning courses and programmes as alternative options in the future. Several felt,

...for Australian TAFE and universities...the school should make more online programmes...for the TAFE schools, students and international students can choose other programmes from other universities...for exam Deakin University has a lot of online degree...for TAFE, only onshore courses... what about people who cannot come onshore? TAFE needs to think about the ways for more courses...(Participant \#20, Interview)

...before the coronavirus...I was thinking...should I move to Melbourne or Brisbane for university...but I discovered that many universities offer online degree courses...so I can go back to my homeland and start my job and placement...in my homeland...not all students like that...but it is a way out...people have their choice...(Participant 15, Focus Group)

In conclusion, and based on the Social Cognitive Career and Motivation Theory (Dos Santos, 2021a; Lent et al., 1994; Lent \& Brown, 1996), the achievements of education and career goal played an important role in this theme. With the development of technologically-assisted teaching and learning tools, many believed that technology could connect students from different parts of the world to a classroom environment with the same level of contribution. Although some schools and teachers are not ready for technologically-assisted teaching and learning in the classroom environments (Moorhouse, 2020; Pike, 2015), distance-learning and online options should be developed and continued to meet the needs and desires of contemporary students and their potential employers. Many expressed that the current arrangement of technologically-assisted teaching satisfied their expectations, confirming the achievements of education and career goal factor. 


\subsection{The Interaction between Teachers and Classmates Remain the Same}

One of the biggest concerns in online distance-based learning is in interaction and peer-to-peer exchanges (Peeters, 2018). Online learning is unlike the traditional classroom environment where students, teachers, and administrative staff exchange ideas in the physical classroom environment and communicate both verbally and physically with each other. A previous study (Alhamami, 2018) indicated that in some foreign language classrooms, communication skills may not develop with technology and computer-assisted tools (Damayanti \& Rachmah, 2020). However, over three-quarters of the participants' group felt that the interaction between teachers and classmates remained the same when using technologically-assisted tools in their classroom environment. Several interesting comments were captured,

...I can communicate with my classmates...we have a Whatsapp group for different courses...we sent messages, projects, and homework to each other...many of us return home...some returned to some town in Australia...and I went back to my homeland...no one actually stayed in the school...it sounded like it is far away...but I think it is really great...and effective...(Participant \#17, Interview)

...I don't think we need to have the in-person communication...to communicate with each other...we can talk over the phone...I call my grandmother from my cell phone too...we don't live together in the same city...but we can talk to each other everyday...the same case...with my teachers and classmates...we have email...we can send messages to all classmates...but my teachers did not understand...but it will not make us [students]...cannot learn from the courses...we learnt together without borders...(Participant \#6, Interview)

Many participants considered that virtual meetings and conferences will be the trend in future education and business environments. The drive for globalisation means that many international businesses and companies work closely together to create a better business and human resources environment. For example, it is difficult for foreign nationals to come to other countries for a recruitment interview; however, due to the COVID-19 Pandemic, many companies have accepted the advantages of virtual interviews for recruitment, particularly in Australia. These strategies can be applied in the educational environment, particularly within teaching and learning. The researcher captured the following comments related to this,

...in these two or three terms...we used the google classroom, Microsoft classroom, and the Zoom classroom...systems...it depends on the school...in my school...the school is using the google classroom...my dad in my homeland...is using the Zoom...to chat with his business partner in the United States....it is the trend for the next decades...business companies can do that...of course the schools and universities can do that too...(Participant \#4, Focus Group)

...I am glad that I can chat...with my teachers, professors, and classmates...in the online classroom platform...after this term, I will continue my education in a university...I conducted the admission interview...with the Zoom conference call...it is very good...the admission office understood our situation...the border...they offered the help over the internet...many years ago...we can only exchange emails...now...we can talk to each other...with no fees...(Participants \#19, Interview)

In conclusion, interaction and communication with teachers in classrooms are among the key factors in education. Although the participants could not enjoy face-to-face interactions with others due to the COVID-19 Pandemic, technologically-assisted teaching and learning strategies and tools have continued to offer alternative ways (Evans, 2014; Roney et al., 2017). All participants considered that social media, online chat groups, email, and cell phone messaging make up some of the communication channels for contemporary students. As many projects, readings, and homework involve contributions from online learning platforms, none of the participants expressed any difficulties in using these tools. More importantly, all believed that online distance-based options will 
become one of the popular learning ways in Australian schools and universities in the future (Tayan, 2017).

\section{Limitations and Future Research Directions}

First of all, COVID-19 Pandemic is a global public crisis. International students face the challenges of loneliness and limited interactions between their peers and teachers. However, it is not uncommon that domestic students also face the same problems and challenges in their home country due to the recommendation of social distancing. Therefore, future research studies should explore similar topics and studies with domestic students in order to cover the wider perspectives.

Second, all education institutions in Australia face the same problems of student enrolment, particularly international students' enrolment management. However, due to the limited research design, only one TAFE institution was invited. Future research studies should expand the aims and focuses from TAFE institutions to universities. In these cases, the holistic pictures will be explored and outlined.

Third, Australia is a popular country for study abroad and international exchange programmes. However, other countries, such as the United States, the United Kingdom, Canada, and New Zealand, are popular educational destinations of international students. Due to the COVID-19 Pandemic, many international students decided to defer their study abroad decision. It is worth noting that these countries, schools, and universities face the same challenges as Australian TAFE and universities. Therefore, research studies should explore and investigate the problems in other countries. After the results were concluded, the researcher may compare and conclude the similarities and difficulties between the various countries and regions.

\section{Implications and Conclusion}

The results of this study will contribute to different channels. First, the international students' population is significantly important for many schools, colleges, and universities. After the points of students, the COVID-19 Pandemic impacted the learning decisions and approaches of all students globally. Although many schools employed the technologically-assisted teaching and learning tools and online learning options, many students decided to defer their learning plans until further notification. However, in this case, all continued their studies with distance-learning approach as international students in their home country. Therefore, the results of this study will fill up the gaps in international students' learning motivation, decision-making process, and intention of distancelearning during and after the COVID-19 Pandemic.

Second, the school leadership and department heads will be beneficial. Before the COVID-19 Pandemic, most of the courses and programmes were offered via the face-to-face option. Although the distance-learning, online, and blended-learning approaches were available, not all were ready for the alternative ways. The comments and opinions from the participants provided the perspectives from students (i.e. about how to improve the experiences and learning instruction). The school leaders should take the comments and recommendations from the participants for further improvements.

Third, government departments and policymakers should take this study as the opportunity for further development and improvement of international students' policy, visa issues, and residency. Although international students do not have permanent residency in Australia, they spend financial resources for their education, study abroad experiences, and Australian qualification. The related staff should invest return plans for international students who have previously gained the re-entry permit to Australia. 


\section{Acknowledgement}

This study was supported by Woosong University Academic Research Funding 2021.

\section{References}

Alhamami, M. (2018). Beliefs about and intention to learn a foreign language in face-to-face and online settings. Computer Assisted Language Learning, 31(1-2), 90-113. https://doi.org/10.1080/09588221.2017.1387154

Almog, D., Chasidim, H., \& Shlomo, M. (2018). Quality and testing: New teaching approaches for software engineers. World Transactions on Engineering and Technology Education, 16(2), 140-145.

Alqurashi, E. (2017). Self-efficacy and the interaction model as predictors of student satisfaction and perceived learning in online learning environments. Duquesne University.

Austin, G. (2010). Administrative challenges and rewards of online learning in a rural community college: Reflections of a distance learning administrator. New Directions for Community Colleges, 150, 27-36. https://doi.org/10.1002/cc.402

Bates, R., \& Khasawneh, S. (2007). Self-efficacy and college students' perceptions and use of online learning systems. Computers in Human Behavior, 23(1), 175-191. https://doi.org/10.1016/j.chb.2004.04.004

Blazar, D., Gilbert, B., Herlihy, C., \& Gogolen, C. (2018). Using tablets to explore the potential for video-based classroom observations for research and professional development. International Journal of Education in Mathematics, Science and Technology, 6(2), 122-135. https://doi.org/10.18404/ijemst.408935

Booy, C., Jansen, N., Joukes, G., \& Van Schaik, E. (2012). Trend analysis gender in higher STEM Education. National Expert Organisation Girls/Women and Science/Technology.

Brown, M., Hughes, H., Keppell, M., Hard, N., \& Smith, L. (2015). Stories from students in their first semester of distance learning. The International Review of Research in Open and Distributed Learning, 16(4). https://doi.org/10.19173/irrodl.v16i4.1647

Creswell, J. (2012). Qualitative inquiry and research design: Choosing among five approaches. Sage.

Creswell, J. (2014). Research design: Qualitative, quantitative, and mixed methods appraoches (4th ed.). Sage.

Damayanti, F., \& Rachmah, N. (2020). Effectiveness of online vs offline classes for EFL classroom: A case in a higher education. Journal of English Teaching, Applied Linguistics and Literatures, 3(1), 19-26.

Dos Santos, L. M. (2020a). Technologically assisted teaching approach: The visual-only video teaching strategy in the nursing education classroom. Universal Journal of Educational Research, 8(12A), 7853-7863. https://doi.org/10.13189/ujer.2020.082574

Dos Santos, L. M. (2020b). The motivation and experience of distance learning engineering programmes students: A study of non-traditional, returning, evening, and adult students. International Journal of Education and Practice, 8(1), 134-148. https://doi.org/10.18488/journal.61.2020.81.134.148

Dos Santos, L. M. (2021a). Developing bilingualism in nursing students: Learning foreign languages beyond the nursing curriculum. Healthcare, 9(3), 326. https://doi.org/10.3390/healthcare9030326

Dos Santos, L. M. (2021b). Motivations and experiences in a distance learning-based degree programme: A case study from a community college. Academic Journal of Interdisciplinary Studies, 10(2), 35. https://doi.org/10.36941/ajis-2021-0036

Dos Santos, L. M. (2020c). Employing a technologically-assisted teaching and learning strategy in the English as a foreign language classroom: The application of the visual-only video teaching strategy. International Conference on Open and Innovative Education, 143-156.

Espino, J., Suárez, M., \& González-Henríquez, J. (2020). Video for teaching: Classroom use, instructor selfproduction and teachers' preferences in presentation format. Technology, Pedagogy and Education, 29(2), 147-162. https://doi.org/10.108o/1475939X.2020.1726805

Evans, C. (2014). Twitter for teaching: Can social media be used to enhance the process of learning? British Journal of Educational Technology, 45(5), 902-915. https://doi.org/10.1111/bjet.12099

Ewing, L.-A., \& Cooper, H. B. (2021). Technology-enabled remote learning during Covid-19: Perspectives of Australian teachers, students and parents. Technology, Pedagogy and Education, 30(1), 41-57. https://doi.org/10.1080/1475939X.2020.1868562

Floyd, D. (2003). Distance learning in community college leadership challenges for change and development. Community College Journal of Research and Practice, 27, 337-347. https://doi.org/10.108o/1066892039012896o 
Heidrich, L., Victória Barbosa, J., Cambruzzi, W., Rigo, S., Martins, M., Dos Santos, R., \& Scherer, B. (2018). Diagnosis of learner dropout based on learning styles for online distance learning. Telematics and Informatics, 35(6), 1593-1606. https://doi.org/10.1016/j.tele.2018.04.007

Kaur, M. (2013). Blended learning: Its challenges and future. Procedia - Social and Behavioral Sciences, 93, $612-617$. https://doi.org/10.1016/j.sbspro.2013.09.248

Lent, R. W., \& Brown, S. D. (1996). Social cognitive approach to career development: An overview. The Career Development Quarterly, 44(4), 310-321. https://doi.org/10.1002/j.2161-0045.1996.tboo448.x

Lent, R. W., Brown, S. D., \& Hackett, G. (1994). Toward a unifying social cognitive theory of career and academic interest, choice, and performance. Journal of Vocational Behavior, 45(1), $79-122$. https://doi.org/10.1006/jvbe.1994.1027

Merriam, S. B. (2009). Qualitative research: A guide to design and implementation. Jossey Bass.

Moorhouse, B. (2020). Adaptations to a face-to-face initial teacher education course 'forced' online due to the COVID-19 pandemic. Journal of Education for Teaching, 46(4), 609-611. https://doi.org/10.108o/o2607476.2020.1755205

Morgan, D. (1998). The focus group guidebook. SAGE Publications, Inc. https://doi.org/10.4135/9781483328164

Mozelius, P., \& Hettiarachchi, E. (2017). Critical factors for implementing blended learning in higher education. International Journal of Information and Communication Technologies in Education, 6(2), 37-51. https://doi.org/10.1515/ijicte-2017-0010

Peeters, W. (2018). Applying the networking power of Web 2.0 to the foreign language classroom: A taxonomy of the online peer interaction process. Computer Assisted Language Learning, 31(8), 905-931. https://doi.org/10.108o/o9588221.2018.1465982

Pike, P. (2015). Using a synchronous online teaching internship to develop pedagogical skills and explore teacher identity: A case study. Journal of Music, Technology and Education, 8(3), $227-242$. https://doi.org/10.1386/jmte.8.3.227_1

Pozdnyakova, O., \& Pozdnyakov, A. (2017). Adult students' problems in the distance learning. Procedia Engineering, 178, 243-248. https://doi.org/10.1016/j.proeng.2017.01.105

Roney, L. N., Westrick, S. J., Acri, M. C., Aronson, B. S., \& Rebeschi, L. M. (2017). Technology use and technological self-efficacy among undergraduate nursing faculty. Nursing Education Perspectives, 38(3), 113118. https://doi.org/10.1097/o1.NEP.ooooooooooooo141

Simpson, O. (2018). Supporting students in online, open and distance learning. Routledge. https://doi.org/10.4324/9780203417003

Smith, R. O. (2008). Adult learning and the emotional self in virtual online contexts. New Directions for Adult and Continuing Education, 120(1), 35-43. https://doi.org/10.1002/ace.314

Strauss, A., \& Corbin, J. M. (1990). Basics of qualitative research: Grounded theory procedures and techniques. Sage.

Tang, K. H., \& Dos Santos, L. M. (2017). A brief discussion and application of interpretative phenomenological analysis in the field of health science and public health. International Journal of Learning and Development, 7(3), 123-132. https://doi.org/10.5296/ijld.v7i3.11494

Tayan, B. (2017). Students and teachers' perceptions into the viability of mobile technology implementation to support language learning for first year business students in a Middle Eastern university. International Journal of Education and Literacy Studies, 5(2), 74. https://doi.org/10.7575/aiac.ijels.v.5n.2p.74

Thatcher, A., Zhang, M., Todoroski, H., Chau, A., Wang, J., \& Liang, G. (2020). Predicting the impact of COVID-19 on Australian universities. Journal of Risk and Financial Management, 13(9), 188. https://doi.org/10.3390/jrfm13090188

Yamagata-Lynch, L. C., Do, J., Skutnik, A. L., Thompson, D. J., Stephens, A. F., \& Tays, C. A. (2015). Design lessons about participatory self-directed online learning in a graduate-level instructional technology course. Open Learning: The Journal of Open, Distance and e-Learning, 30(2), 178-189. https://doi.org/10.1080/02680513.2015.1071244

Yin, R. K. (2012). Applications of case study research (3rd ed.). SAGE Publications. 